\title{
The Socio-Economic Impact of the Greater Port Harcourt Development Project on the Residents of the Affected Areas
}

\author{
Elenwo Ephraim Ikechukwu \\ Department of Geography and Environmental Management, University of Port Harcourt, \\ Choba, Nigeria \\ Email: Iyke2 elenwo@yahoo.com, ephraimelennwo@gmail.com
}

Received 18 December 2014; accepted 3 January 2015; published 22 January 2015

Copyright (C) 2015 by author and Scientific Research Publishing Inc.

This work is licensed under the Creative Commons Attribution International License (CC BY). http://creativecommons.org/licenses/by/4.0/

c) (7) Open Access

\section{Abstract}

This study investigates the relationship between the socio-economic affected Communities and the Greater Port Harcourt Development Project in Rivers State. The data used for study were obtained through questionnaire. The generated data were analyzed using the factor analysis and paired $t$ test. It was observed that the computed $t$-scores $(-2.729)$ and $(-2.895)$ exceeded the values of $t$, indicated in the table. The T-test, values showed that the occurrence of hazards and risks on the residents of affected communities in Port Harcourt was significantly related to the activities of greater Port Harcourt project, and also the socio economic life of residents of the communities was significantly affected by the activities of greater Port Harcourt project. The study has shown that there is an undercurrent of dissatisfaction with the greater Port Harcourt project in many of the comments put forward by the communities because of historical reasons. However, whatever reasons the host communities may have is manifestly not strong enough to stop the government in its proposal to transform the city decay to a world class city internationally recognized for excellence.

\section{Keywords}

Socio-Economic, Impacts, Communities, Affected, Greater Port Harcourt

\section{Introduction}

New Towns are seen as new settlements built away from the congested urban centers that are economically and socially independent of the older cities or towns. They are designed to offer healthier, more efficient and satis- 
fying environment. However, their philosophies vary slightly from one era and country to another. Over the years, especially in developing countries, the rural areas continue to push out human and material resources; the urban areas continue to absorb these resources, most times to its detriment. The pushing out and pulling in have in the main exacerbated the seemingly intractable problems which are concomitant with urbanization. Port Harcourt city has long played the role of a gate way to the northern and eastern Nigeria and even beyond to neighbouring countries such as Niger and Benin Republic etc. The sea port is the natural focus of the rail and road routes of the eastern region and the coal field at Enugu, the tin mines in Jos and the Beniseed and Soya bean producing region around Markurdi. These commodities became early exports in addition to oil palm, rubber, palm kernels and cocoa of the southern forest zone and ground nut and cotton of northern Nigeria [1]. Port Harcourt sea port is the second largest port in Nigeria and handles some importation and exportation activities for the eastern parts of the country.

In recent times, the Petroleum industry has had a direct and significant impact on the growth of the city of Port Harcourt. Both in regional and national context, the city has remained an important urban area because of its commercial activities, large sea port, good railway terminal, a modern international air port and one of the best planned urban centre in Nigeria (the garden city). Port Harcourt city has increased steadily and rapidly since its foundation. According to the 1952-53 population census of Nigeria, the population of Port Harcourt was 79, 634. In 1963, it rose to 179, 563, which represents an average annual growth rate of 8.7 percent. From 1963 t0 1972, the population of Port Harcourt was estimated to have risen from 179,563 to 213,343, an annual growth rate of almost three percent [2]. By 1973, Port Harcourt Population stood at 231, 632. The 1991 census figure put the population of Port Harcourt/Obio-Akpor city local government areas at 703,416, with Obio/Akpor accounting for 263,017 and Port Harcourt city local government area at 440,399 [3].

The growth and expansion of the city of Port Harcourt has been through the submerging of neighbouring independent villages into a rapidly growing conurbation. Today, the city has grown in spatial terms from the mere 40 square kilometer area by 1912-1913 Hargrove agreement to about 313 square kilometer [3]. This astronomical growth has made obsolete the city's master plan of 913 and 1975 respectively. The above facts have greatly influenced the presence of Federal projects such as liquefied natural gas project phase 1 and 11, export processing zone (EPZ) at Onne; Head offices of multi-national companies such as SPDC, Total-Fina Elf and NAOC etc which are of strategic economic importance to the area. These serve as centripetal or magnetic pull in attracting immigrants into the already congested city. More so, the city plays host to a number of higher institutions; the University of Port Harcourt, the Rivers State University of Science and Technology, Ignatius Ajuru University of Education, the Rivers state College of Arts and Science and the Rivers State College of Health Technology to mention a few. These activities culminates on the attendant congestion experienced in all sectors of the city today which creates the need for decongestion of the city by establishment of new towns as proposed by the Greater Port Harcourt Development Authority. This study is set to ascertain the effect of greater Port Harcourt project on the residents of the host communities.

\section{The Study Area}

Port Harcourt, the capital of Rivers State is situated in the sub-equatorial region and lies in a peninsula approximately $4^{\circ} 421$ North and $4^{\circ} 471$ North latitude and $6^{\circ} 551$ east, $7^{\circ} 081$ East longitude (see Figure 1). It is located on the eastern part of Rivers State and the metropolitan area occupies about 180,000 hectares [4]. The city came into prominence with the desire of the British colonial government in Nigeria at the time in 1912 to construct a railway line from the interior to the coast to move agricultural produce and other natural resources. Thus, the railway and a terminus were constructed in Port Harcourt linking the interior to the coast in 1927. The construction of the railway and harbour attracted more business from within and other parts of the world making the city to quickly acquire a cosmopolitan status and more so, the discovery of oil aggravated this influx of people, thereby making the city to expand rapidly till today. Port Harcourt consists of relatively flat land with a gradient of not more than $3 \%$. Its elevation is $3 \mathrm{~m}$ at the lower limits of the dry land and $2.5 \mathrm{~m}$ tidal variation [4]. The city has a low-lying coastal plain that rarely rises above $60 \mathrm{ft}(20 \mathrm{~m})$ above sealed level. The Northern coastal terrain consists of dry land, but the lower delta plain consists of small isolated island of firm ground in the vast delta which is continuously being rearranged by strong tidal and flood current [4]. The city has a high water table, with an upper soil layer of soft mud, of $(6 \mathrm{~m})$ thick having high organic material in the delta. The dry land area has an upper soil layer of silt and sand of the same thickness [4]). 


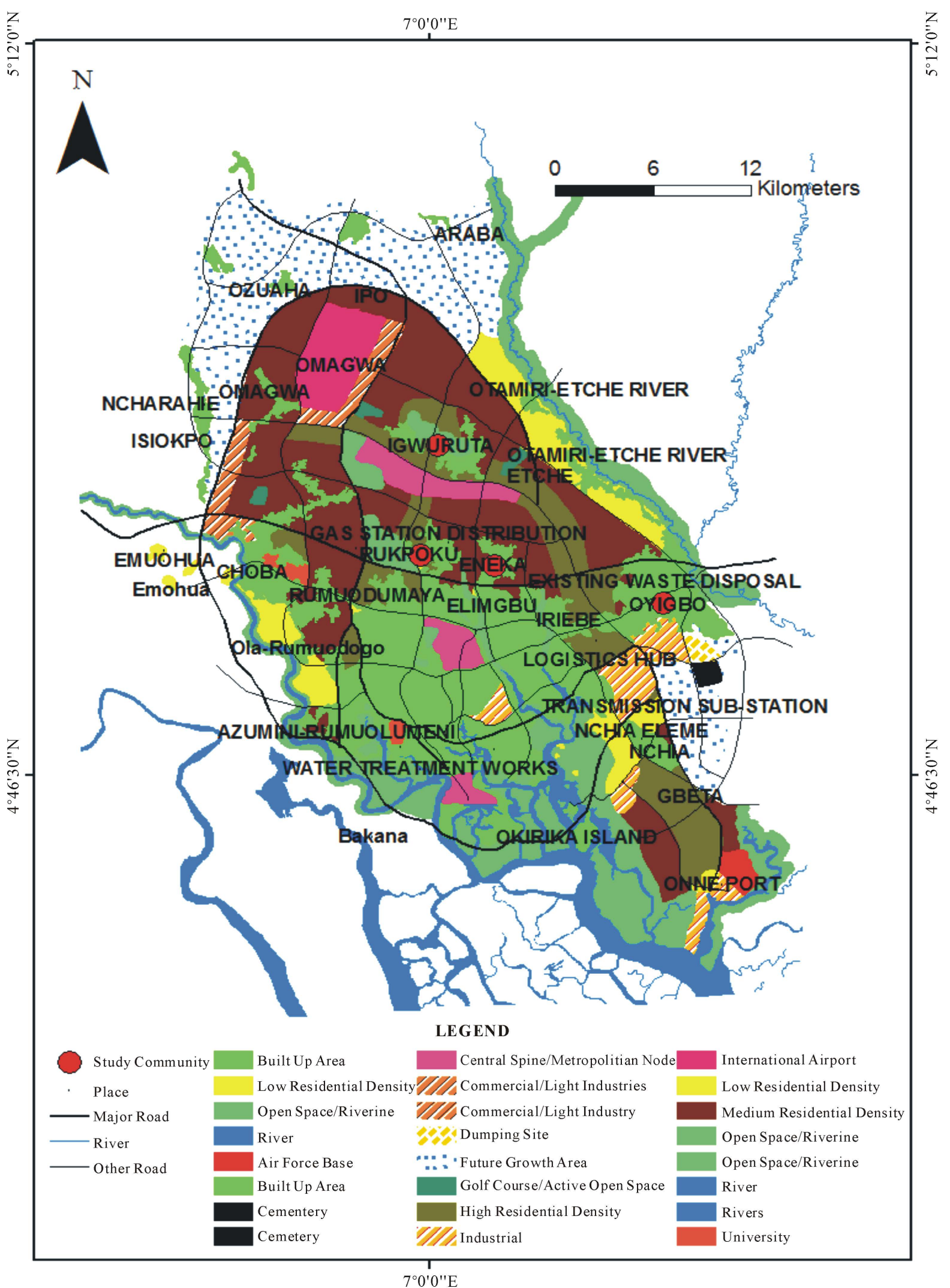

Figure 1. Greater port Harcourt City, rivers state [5]. 
Port Harcourt has a tropical climate with an annual mean temperature of $30^{\circ} \mathrm{C}\left(86^{\circ} \mathrm{F}\right)$ and a relative humidity of between $80 \%-100 \%$ [4]. These conditions support the easy decay of organic materials. It has rain fall all year round with the highest of $480 \mathrm{~mm}$ between July and September. Although having a small break in between the month of August, its drier months are from December to February but its mean yearly rainfall is about 23,000 mm. Port Harcourt has a relatively still air condition and the prevailing wind being basically south-west and north-East trade wind. About $47 \%$ of the period experiences no wind while $2 \%$ of the time witnesses a wind speed of between 5 to 7 meters/second, only rarely does it exceed 17 meters/second [4].

\section{Methods of Data Collection}

The study adopted the field survey of the communities affected by the greater Port Harcourt. The sample for the study was drawn using a multi stage systematic random sampling and simple random sampling techniques. At the first stage, a sample frame was designed to depict the grid system across the Greater Port Harcourt Spatial Development Plan (GPHSDP) as shown in Table 1.

From Table 1, the designed grid squares tally with the grid on the Greater Port Harcourt Spatial Development Plan (GPHSDP). These numbers were written on pieces of papers, folded and then placed in a container. The papers shaken and the number 18 were drawn at random, and were recorded (see Table 2).

In order to have a representative sample of the selected seven community out of the eight communities covered by the Greater Port Harcourt Project, the selected seven communities were subjected to another random sampling technique and at the end, four communities were randomly chosen for the study, they are Rukpoku, Omagwa, Eneka and Oyigbo communities respectively (see Table 2). The Greater Port Harcourt covers an area of approximately 1900 square Kilometres (190,000 Hectares of land) spanning eight local government area with a projected population of about two million $(2,000,000)$ persons. Therefore to get a sampling ratio for the study, the researchers wish to draw a sample of 400 persons from the selected communities, e.g., 400/2,000,000 = $0.0002 \%$ or $0.2 \%$ of the population would be sampled.

Table 1. Selections of communities from the (GPHSDP).

\begin{tabular}{ccccccc}
\hline & 1 & 2 & 3 & 4 & 5 & 6 \\
\hline A & 1 & 8 & 15 & 22 & 29 & 36 \\
B & 2 & 9 & 16 & 23 & 30 & 37 \\
C & 3 & 10 & 17 & 24 & 31 & 38 \\
D & 4 & 11 & 18 & 25 & 32 & 39 \\
E & 5 & 12 & 19 & 26 & 33 & 40 \\
F & 6 & 13 & 20 & 27 & 34 & 41 \\
G & 7 & 14 & 21 & 28 & 35 & 42 \\
\hline
\end{tabular}

Table 2. List of selected communities in the study area.

\begin{tabular}{ccccc}
\hline S/n & Number drawn & Code & Names of Communities & Local Government Area \\
\hline 1 & 18 & D3 & Rukpoku $^{*}$ & Obio/Akpor \\
2 & 10 & C2 & Omagwa $^{*}$ & Ikwerre \\
3 & 25 & D4 & Eneka $^{*}$ & Obio/Akpor \\
4 & 19 & E3 & Ozuoba & Obio/Akpor \\
5 & 27 & F4 & Okirika Island $^{*}$ & Okirika \\
6 & 32 & D5 & Oyigbo & Oyigbo \\
7 & 42 & G6 & Ogu & Ogu/Bolo \\
\hline
\end{tabular}

${ }^{*}$ Selected communities. 
The study adopted administration of questionnaire to obtained data on the socio-economic impact of the greater Port Harcourt project on the residents of the affected areas. The questionnaire administration was carried out by means of face to face interviews. On the whole a total of 400 questionnaires were administered in the four communities on the basis of 100 in each selected community in the study area, and focus group discussion. The data were presented with statistical diagram and analyzed with multivariate statistics such as factor analysis. Factor analysis is a high powered multivariate statistical technique used in explaining observed relationships among numerous variables in terms of fewer and simpler mutually independent factors. This is achieved by collapsing a set of inter-correlated variables into smaller numbers of basic dimensions, which are capable of explaining a high percentage of variance in the original data set. The basic dimension or common factors are thus diagnostic of the underlying influence structure [6]. The factor analysis technique extracts from given set of variables of " $n$ " variables " $m$ " orthogonal dimensions (where $m>n$ ). The " $m$ " dimension generally represents a large part of the original variance among the "n" variables. The factor analysis model is given as:

$$
\mathrm{Zj}=\mathrm{ajiF} 1+\mathrm{aj}-\mathrm{F} 2 \cdots \operatorname{ajmfm}+\mathrm{djuj}
$$

where $\mathrm{Zj}=$ variables $\mathrm{j}$ in standardized form.

F1F2 = hypothetical factor.

$\mathrm{Uj}=$ standardized multiple regression coefficient or I commonly referred to as factor loading.

$\mathrm{Dj}$ = standardized regression coefficient of variable or unique Factor $\mathrm{j}$.

The factor analysis was used to ascertain the significant effects of greater Port Harcourt project on socio economic lives of resident of affected communities, as well as the significant hazards and risks faced by communities affected by the Greater Port Harcourt Development Project.

\section{Results and Discussion}

Table 3 showed that the population was fairly evenly distributed between the youngest age cohorts (those less than 20 years old), the younger productive age groups (20 - 44 years), and the older productive age groups and retirees (over 45 years). This type of distribution is not consistent with the typical bottom-heavy population

\begin{tabular}{ccccc|}
\hline \multicolumn{5}{c}{ Table 3. Age-sex distribution in the study area (percentage distribution). } \\
\hline $\begin{array}{c}\text { Age Cohorts } \\
\text { (Years) }\end{array}$ & Male & \multicolumn{3}{c|}{ Female } \\
\cline { 2 - 5 } $0-4$ & - & - & N & $\%$ \\
$5-9$ & - & - & - & - \\
$10-14$ & 14 & 5.34 & 10 & - \\
$15-19$ & 26 & 9.92 & 12 & 7.24 \\
$20-24$ & 10 & 3.81 & 9 & 8.69 \\
$25-29$ & 16 & 6.10 & 11 & 6.52 \\
$30-34$ & 18 & 6.87 & 12 & 7.97 \\
$35-39$ & 14 & 5.34 & 10 & 8.69 \\
$40-44$ & 28 & 10.68 & 13 & 7.24 \\
$45-49$ & 40 & 15.26 & 12 & 9.42 \\
$50-54$ & 25 & 9.54 & 14 & 10.69 \\
$55-59$ & 21 & 8.01 & 12 & 8.69 \\
$60-64$ & 30 & 11.45 & 10 & 7.24 \\
65 and above & 20 & 7.63 & 13 & 9.42 \\
Total & 262 & 100.00 & 138 & 100.00 \\
\hline
\end{tabular}


structure for developing countries and regions. For Nigeria as a whole, for instance, as at the 1991 census [7], the three broad age cohorts referred to above, accounted for about 9.92, 10.6.8 and 15.26 percent, respectively.

Table 4 shows the household educational attainment in the four communities. On the whole, educational attainment tended to be dominated by secondary/vocational/Technical school level achievement with a percentage of $37 \%$, followed by those with Polytechnics/University certificates with $26.8 \%$, while those with Primary school and none formal education are $12 \%$ and $24 \%$ respectively.

The occupational distribution of the inhabitants in the four communities is shown in Table 5 . And it reveals that contracting (31\%) is the most importance occupation in the area. This could ascribe to the emerging city development in these communities, followed by clerical office workers (25\%), and unemployed persons (23\%). Trading and farming were $6 \%$ and $5 \%$ respectively and Drivers/Technicians are $12 \%$.

Table 6 discuses the status of the buildings/property in the affected communities. And it showed that $51 \%$ of the buildings were built by their owners while $49 \%$ bought their buildings.

Table 7 shows the land status of residents of affected communities, and it revealed that $68 \%$ of the lands in the area were bought, while $32 \%$ were owned by indigenes of the communities.

Table 8 shows the income distribution per household in the communities. At a glance, it reveals that most of the residents earn above $\$ 100,000$, this confirms the aforementioned in the occupational distribution of house household member as contractors. This is followed by $\$ 8000$ and above (32\%), which are in the class of clerical office workers $24 \%$. Other income categories are as represented in Table 8.

Table 9 shows the four communities, a summary of respondents' first, second and third mentions, regarding their perceived benefits of Greater Port Harcourt Development projects (GPHDP) on affected communities.

Table 4. Educational status of community members.

\begin{tabular}{|c|c|c|c|c|c|}
\hline & & Frequency & Percent & Valid Percent & Cumulative Percent \\
\hline \multirow{5}{*}{ Valid } & Polytechnic/University & 107 & 26.8 & 26.8 & 26.8 \\
\hline & Primary School & 48 & 12.0 & 12.0 & 38.8 \\
\hline & Secondary/Vocational/Technical School & 148 & 37.0 & 37.0 & 75.8 \\
\hline & None & 97 & 24.2 & 24.2 & 100.0 \\
\hline & Total & 400 & 100.0 & 100.0 & \\
\hline
\end{tabular}

Table 5. Occupational status of community members.

\begin{tabular}{|c|c|c|c|c|c|}
\hline & & Frequency & Percent & Valid Percent & Cumulative Percent \\
\hline \multirow{7}{*}{ Valid } & Contractor & 123 & 30.8 & 30.8 & 30.8 \\
\hline & Labourers/Apprentice/Clerical Office Workers & 98 & 24.5 & 24.5 & 55.2 \\
\hline & Technicians/Drivers & 47 & 11.8 & 11.8 & 67.0 \\
\hline & Unemployed & 93 & 23.2 & 23.2 & 90.2 \\
\hline & Trading & 18 & 4.5 & 4.5 & 94.8 \\
\hline & Farming/Fishing & 21 & 5.2 & 5.2 & 100.0 \\
\hline & Total & 400 & 100.0 & 100.0 & \\
\hline
\end{tabular}

Table 6. Building status.

\begin{tabular}{cccccc}
\hline & & Frequency & Percent & Valid Percent & Cumulative Percent \\
\hline \multirow{3}{*}{ Valid } & Bought & 195 & 48.8 & 48.8 & 48.8 \\
& Built & 205 & 51.2 & 51.2 & 100.0 \\
& Total & 400 & 100.0 & 100.0 & \\
\hline
\end{tabular}


Table 7. Land status.

\begin{tabular}{cccccc}
\hline & & Frequency & Percent & Valid Percent & Cumulative Percent \\
\hline \multirow{4}{*}{ Valid } & Bought & 271 & 67.8 & 67.8 & 67.8 \\
& Family Land (Inherited) & 129 & 32.2 & 32.2 & 100.0 \\
& Total & 400 & 100.0 & 100.0 & \\
\hline
\end{tabular}

Table 8. Percentage distribution of household income in the study area.

\begin{tabular}{|c|c|c|c|c|c|c|}
\hline S/No. & $\begin{array}{l}\text { Household Commun } \\
\text { Income (Monthly) }\end{array}$ & Eneka & Igwuruta & Oyigbo & Rukpoku & Total \% \\
\hline 1 & Less than $\$ 10,000$ & 4.1 & 3.1 & 6.7 & 5.3 & 19.2 \\
\hline 2 & $\$ 10,000-19,999$ & 3.1 & 4.6 & 6.7 & 3.1 & 17.5 \\
\hline 3 & $\$ 20,000$ - 29,999 & 1.5 & 1.5 & 3.3 & 1.5 & 7.8 \\
\hline 4 & $\$ 30,000-39,999$ & 0 & 3.1 & 0 & 2.7 & 5.8 \\
\hline 5 & $\$ 40,000$ - 49,999 & 0 & 3.1 & 6.7 & 0 & 9.8 \\
\hline 6 & $\$ 50,000$ - 59,999 & 1.0 & 4.6 & 0 & 1.2 & 6.8 \\
\hline 7 & \$60,000 - 79,999 & 2.0 & 4.2 & 1.0 & 3.0 & 10.2 \\
\hline 8 & $\$ 80,000$ - 99,999 & 5.2 & 3.7 & 10.3 & 5.1 & 24.3 \\
\hline 9 & $\$ 100,000$ and above & 5.5 & 10.3 & 10.7 & 5.5 & 32.0 \\
\hline
\end{tabular}

Table 9. Perceived benefits of the greater port Harcourt development project on affected communities (percentage distribution).

\begin{tabular}{|c|c|c|c|c|c|c|c|}
\hline \multirow{2}{*}{ S/No. } & \multirow{2}{*}{ Benefits } & \multicolumn{2}{|c|}{ First mentions } & \multicolumn{2}{|c|}{ Second mentions } & \multicolumn{2}{|c|}{ Third mentions } \\
\hline & & $\mathrm{N}$ & $\%$ & $\mathrm{~N}$ & $\%$ & $\mathrm{~N}$ & $\%$ \\
\hline 1 & Improvement in infrastructure & 76 & 39.7 & 65 & 48.5 & 25 & 33.3 \\
\hline 2 & Increase commercial activities & 40 & 20.9 & 14 & 10.5 & 25 & 33.3 \\
\hline 3 & Employment & 45 & 23.6 & 25 & 18.7 & 5 & 6.6 \\
\hline 4 & Improvement in agriculture & 10 & 5.2 & 10 & 7.5 & 5 & 6.6 \\
\hline 5 & Scholarships & 10 & 5.2 & 10 & 7.5 & 10 & 13.3 \\
\hline 6 & $\begin{array}{l}\text { Improvement in community } \\
\text { company relationship }\end{array}$ & 6 & 3.1 & 8 & 5.9 & 3 & 4.0 \\
\hline \multirow[t]{2}{*}{7} & Others & 4 & 2.1 & 2 & 1.5 & 2 & 2.6 \\
\hline & Total & 191 & 100 & 134 & 100 & 75 & 100 \\
\hline
\end{tabular}

Amongst first mentions, improvement in infrastructure emerged as the modal perceived benefit (122\%); "increase in commercial activities" and "employment" was the modes amongst second and third mentions (65\% and $49 \%$, respectively.

Table 10 shows the effects of GPHDP presence on the affected communities. The table at a glance shows that about $33.5 \%$ of affected communities were displaced, $45.8 \%$ lost their buildings, and $6.0 \%$ lost ownership of their land, property and farm. Furthermore, $8.5 \%$ had psychological problems and $6.2 \%$ were sick for different ailments and diseases. It is obvious from the analysis on the table above that the GPHDP affected the communities negatively. 
Table 10. Effects of GPHDP Presence on the affected communities.

\begin{tabular}{ccc}
\hline & Frequency & Percentage (\%) \\
\hline Displacement & 134 & 33.5 \\
Loss of building & 183 & 45.8 \\
Loss of ownership of Land/property/farm & 24 & 6.0 \\
Psychological effects & 34 & 8.5 \\
Sickness/disease & 25 & 6.2 \\
Total & 400 & 100 \\
\hline
\end{tabular}

Table 11 shows the four communities, a summary of respondents' first, second and third mentions, regarding their perceived adverse effects of Greater Port Harcourt Development Projects (GPHDP) on affected communities. Amongst first mentions, more commercial sex workers emerged as the modal perceived adverse effects (70.0\%); pollution of environment and pressure on existing infrastructure was the modes amongst second and third mentions $57.6 \%$ and $43 \%$, respectively.

Table 12, Table 13 and Table 14 showed the rating of Communities' Pleasure/Displeasure with GPHDP, an important aspect of group discussion, respondents in the target populations were asked to rate their relationship with GPHDP and to highlight the reasons for their ratings. The rating scale was as follows:

1) Very displeased.

2) Somewhat displeased.

3) Neither pleased nor displeased.

4) Somewhat pleased.

5) Very pleased.

From Table 12 and Table 13, the results of the ratings generally revealed that the four communities tended to be more displeased than pleased with GPHDP. The reasons for this kind of situation are summarized in Table 13 and Table 14, respectively.

\subsection{Application of Factor Analysis}

The study also utilized the factor analysis to measure the hazards, risks and socio economic factors faced by communities affected by the Greater Port Harcourt project in Rivers State. This was done to strengthen the explanatory power of the descriptive statistics which was used to analysis results in the study. The factor analysis uses the extraction method to identify the factors that actually explains the physical and socio economic characteristics in the study area. The factor analysis was used to analyze a table of component matrix. A 19 by 19 component matrix, using principal factors analysis as extraction method was used. The communalities indicate the amount of variance in each variable that is accounted for by the factors. The communalities in Table 15 are all high indicating that the extracted factors are true representation of the variables.

Only cases for which socioeconomic = loss of property Intrusion into the privacy of the community are used in the analysis phase in the four communities.

Table 16 shows the extractions of eigen values from total variable rotated factor loading on orthogonal common factors from Table 16. The four communities are represented on Table 16 as four factors which accounted for $78.183 \%$ of the total variance.

The factor analysis and paired $t$ test results are used to test the following hypotheses:

1) That the occurrence of hazards and risks on the residents of affected communities is not significantly related to the activities of greater Port Harcourt project.

2) That the socio economic life of residents of the communities is not significantly affected by the activities of greater Port Harcourt project.

\subsubsection{Test of Hypothesis 1}

The $\mathrm{T}$ test used test this hypothesis is one. Two independent variables were used in pair for the comparison; hazards and risk factors against location. In application of T-test, it is generally known that the normal curve is 
Table 11. Other perceived adverse effects of the GPHDP's on affected communities (percentage distribution).

\begin{tabular}{cccccccc}
\hline \multirow{2}{*}{ S/No. } & \multirow{2}{*}{ Effects } & \multicolumn{2}{c}{ First mentions } & \multicolumn{2}{c}{ Second mentions } & \multicolumn{2}{c}{ Third mentions } \\
\cline { 3 - 8 } & & $\mathrm{N}$ & $\%$ & $\mathrm{~N}$ & $\%$ & $\mathrm{~N}$ & $\%$ \\
\hline 1 & Pollution of environment & 50 & 25.0 & 25 & 7.6 & 25 & 25.0 \\
2 & More commercial sex workers & 50 & 25.0 & 25 & 25.0 & 20 & 20.0 \\
3 & Erosion of cultural and traditional values & 30 & 15.0 & 10 & 10.0 & 10 & 10.0 \\
4 & Reduction in the use of local language & 10 & 5.0 & 10 & 10.0 & 10 & 10.0 \\
5 & Pressure on existing infrastructure & 25 & 12.5 & 15 & 15.0 & 15 & 15.0 \\
6 & Intrusion on privacy & 10 & 5.0 & 10 & 10.0 & 5 & 0.0 \\
7 & Desecration of sacred places & 15 & 7.5 & 0 & 0.0 & 10 & 10.0 \\
8 & Fomentation of conflict & 10 & 5.0 & 5 & 5.0 & 5 & 5.0 \\
9 & Others & 0 & 0.0 & 0 & 0.0 & 0 & 0.0 \\
& Total & 200 & 100 & 100 & 100 & 100 & 100 \\
\hline
\end{tabular}

Table 12. Rating of pleasure and displeasure with GPHDP (percentage distribution).

\begin{tabular}{ccccc}
\hline Community & Eneka & Igwuruta & Oyigbo & Rukpoku \\
\hline Attitude & 63.0 & 69.6 & 42.9 & 43.3 \\
Very Displeased & 29.6 & 0 & 13.1 & 10.0 \\
Somewhat Displeased & 7.4 & 0 & 0 & 3.3 \\
Neither Pleased Nor Displeased & 0 & 0 & 23.7 & 20.0 \\
Somewhat Pleased & 0 & 30.4 & 100.0 & 23.3 \\
Very Pleased & 100.0 & 100.0 & & 100.0 \\
Total & & & & \\
\hline
\end{tabular}

Table 13. Reasons for pleasure with GPHDP.

\begin{tabular}{ccl}
\hline S/No. & Community & \multicolumn{1}{c}{ Reasons for pleasure } \\
\hline 1 & Eneka & Nil \\
2 & Igwuruta & Provided some employment for indigenes \\
3 & Oyigbo & Nil \\
4 & Rukpoku & Provided some employment for indigenes \\
\hline
\end{tabular}

Table 14. Reasons for displeasure with GPHDP in the four communities.

\begin{tabular}{cll}
\hline S/No. & Community & \multicolumn{1}{c}{ Reasons for pleasure } \\
\hline 1 & Eneka & $\begin{array}{l}\text { Displacement } \\
\text { Loss of means of livelihood } \\
\text { Erosion of cultural and traditional values }\end{array}$ \\
& Igwuruta & $\begin{array}{l}\text { Engender inflation and spread of STDs } \\
\text { Inability to provide basic social amenities } \\
\text { No employment }\end{array}$ \\
& Oyigbo & $\begin{array}{l}\text { No employment } \\
\text { Fomentation of conflicts }\end{array}$ \\
& Rukpoku & $\begin{array}{l}\text { No employment } \\
\text { Distrust between GPHDP and host community }\end{array}$ \\
\hline
\end{tabular}


Table 15. Extracted communalities from the nineteen principal factors.

\begin{tabular}{|c|c|c|c|c|}
\hline & \multicolumn{2}{|c|}{ Raw } & \multicolumn{2}{|c|}{ Rescaled } \\
\hline & Initial & Extraction & Initial & Extraction \\
\hline Age & 1.216 & 1.104 & 1.000 & 0.908 \\
\hline Education & 0.377 & 0.307 & 1.000 & 0.813 \\
\hline Occupation & 1.261 & 1.218 & 1.000 & 0.966 \\
\hline Income & 0.913 & 0.666 & 1.000 & 0.730 \\
\hline Build & 0.139 & 0.046 & 1.000 & 0.331 \\
\hline Land & 0.106 & 0.072 & 1.000 & 0.683 \\
\hline Reside & 0.239 & 0.053 & 1.000 & 0.221 \\
\hline Rooms & 0.758 & 0.744 & 1.000 & 0.981 \\
\hline Aware & 0.106 & 0.072 & 1.000 & 0.683 \\
\hline Acquainted & 0.251 & 0.194 & 1.000 & 0.776 \\
\hline Fall_within & 0.044 & 0.032 & 1.000 & 0.733 \\
\hline Compensation & 0.249 & 0.201 & 1.000 & 0.808 \\
\hline Benefit & 0.245 & 0.183 & 1.000 & 0.747 \\
\hline Aspects & 0.507 & 0.347 & 1.000 & 0.684 \\
\hline Displeased & 0.857 & 0.735 & 1.000 & 0.857 \\
\hline Implication & 0.251 & 0.058 & 1.000 & 0.233 \\
\hline Effects & 0.044 & 0.032 & 1.000 & 0.733 \\
\hline Close & 0.268 & 0.008 & 1.000 & 0.030 \\
\hline Hazards & 0.517 & 0.452 & 1.000 & 0.875 \\
\hline
\end{tabular}

Table 16. Extraction of eigen values from total rotated variables.

\begin{tabular}{cccc}
\hline \multirow{2}{*}{ Component } & & Initial Eigen Values & \\
\cline { 2 - 4 } & Total Eigen Values & \% of Variance & Cumulative \% \\
\hline Raw 1 & 3.977 & 47.643 & 47.643 \\
2 & 1.221 & 14.627 & 62.270 \\
4 & .690 & 8.262 & 70.532 \\
\hline
\end{tabular}

distributed about a mean of zero, with a standard deviation of one (1). A, t-score can fall along the normal cure either above or below the mean; either plus or minus some standard deviation unit from the mean. The results are shown in Table 17.

From Table 17, it is observed that the computed t-scores $(-2.729)$ are greater than the values of $t$, indicated in the table. Also, from T-test, there is significant difference at $(\mathrm{p}<0.004)$ between the comparisons done for the pairs. Thus, the null hypothesis is rejected, and we states the occurrence of hazards and risks on the residents of affected communities is significantly related to the activities of greater Port Harcourt project.

\subsubsection{Test of Hypotheses 2}

The socio economic life of residents of the communities is not significantly affected by the activities of greater Port Harcourt project. 
T-Test to test hypothesis 2

The $\mathrm{T}$ test used test this hypothesis is two. Two independent variables were used in pair for the comparison; hazards and risk factors against location. In application of T-test, it is generally known that the normal curve is distributed about a mean of zero, with a standard deviation of one (1). A, t-score can fall along the normal cure either above or below the mean; either plus or minus some standard deviation unit from the mean. The results are shown in Table 18.

From Table 18, it is observed that the computed t-scores (2.895) exceed the values of $t$, indicated in the table. Also, from T-test, there is significant difference at $(\mathrm{p}<0.004)$ between the comparisons done for the pairs. Thus the null hypothesis is rejected, and we states that the socio economic life of residents of the communities is significantly affected by the activities of greater Port Harcourt project.

Table 17. (a) Paired t test samples statistics; (b) Paired samples correlations; (c) Paired samples test.

(a)

\begin{tabular}{cccccc}
\hline & & Mean & N & Std. Deviation & Std. Error Mean \\
\hline \multirow{3}{*}{ Pair 1 } & Hazards & 2.2550 & 400 & 1.23645 & 0.06182 \\
& Location & 2.5000 & 400 & 1.11943 & 0.05597 \\
\hline
\end{tabular}

(b)

\begin{tabular}{cccc}
\hline & N & Correlation & Sig. \\
\hline Pair 1 & Hazards \& Location & 400 & -0.159 \\
\hline
\end{tabular}

(c)

\begin{tabular}{|c|c|c|c|c|c|c|c|c|c|}
\hline & & \multicolumn{5}{|c|}{ Paired Differences } & \multirow{3}{*}{$\mathrm{T}$} & \multirow{3}{*}{ Df } & \multirow{3}{*}{$\begin{array}{c}\text { Sig. } \\
\text { (2-Tailed) }\end{array}$} \\
\hline & & \multirow{2}{*}{ Mean } & \multirow{2}{*}{$\begin{array}{c}\text { Std. } \\
\text { Deviation }\end{array}$} & \multirow{2}{*}{$\begin{array}{l}\text { Std. Error } \\
\text { Mean }\end{array}$} & \multicolumn{2}{|c|}{$\begin{array}{l}\text { 95\% Confidence Interval } \\
\text { of the Difference }\end{array}$} & & & \\
\hline & & & & & Lower & Upper & & & \\
\hline Pair 1 & Hazards-Location & -0.24500 & 1.79528 & 0.08976 & -0.42147 & -0.06853 & -2.729 & 399 & 0.007 \\
\hline
\end{tabular}

Table 18. (a) Paired samples statistics; (b) Paired samples correlations; (c) Paired samples test.

(a)

\begin{tabular}{cccccc}
\hline & & Mean & N & Std. Deviation & Std. Error Mean \\
\hline \multirow{2}{*}{ Pair 1 } & Socio_economic & 2.2400 & 400 & 1.27336 & 0.06367 \\
& Location & 2.5000 & 400 & 1.11943 & 0.05597 \\
\hline
\end{tabular}

(b)

\begin{tabular}{llccc}
\hline & & N & Correlation & Sig. \\
\hline Pair 1 & Socio_economic \& Location & 400 & -0.123 & 0.014 \\
\hline
\end{tabular}

(c)

\begin{tabular}{|c|c|c|c|c|c|c|c|c|c|}
\hline & & \multicolumn{5}{|c|}{ Paired Differences } & \multirow{3}{*}{$\mathrm{t}$} & \multirow{3}{*}{ df } & \multirow{3}{*}{$\begin{array}{c}\text { Sig. } \\
\text { (2-Tailed) }\end{array}$} \\
\hline & & \multirow{2}{*}{ Mean } & \multirow{2}{*}{$\begin{array}{c}\text { Std. } \\
\text { Deviation }\end{array}$} & \multirow{2}{*}{$\begin{array}{l}\text { Std. Error } \\
\text { Mean }\end{array}$} & \multicolumn{2}{|c|}{$\begin{array}{l}\text { 95\% Confidence Interval } \\
\text { of the Difference }\end{array}$} & & & \\
\hline & & & & & Lower & Upper & & & \\
\hline Pair 1 & Socio_economic-Location & -0.26000 & 1.79596 & 0.08980 & -0.43654 & -0.08346 & -2.895 & 399 & 0.004 \\
\hline
\end{tabular}




\section{Limitations in the Study}

The first problem was how to sample the eight local government areas covered by the greater Port Harcourt Project. This was solved by means of simple random sampling technique adopted. Furthermore, the bureaucracy that exists in the public service hampered efforts to obtain primary and secondary data. In spite of all these, the quality of work expected was achieved.

\section{Conclusion}

The study reveals the occurrence of hazards and risks on the residents of affected communities in Port Harcourt, which is significantly related to the activities of greater Port Harcourt project, and also the socio economic life of residents of the communities is affected by the activities of greater Port Harcourt project. But these effects are temporary in nature, as such it is recommended that the state government should continue with the project because, when completed it will transform the city decay to a world class city internationally recognized for excellence.

\section{References}

[1] Ali, M. (1975) Man in West Africa. Ethiope Publishing, Benin, 458 p.

[2] Ogionwo, W. (1979) The City of Port Harcourt. Heinemann Press Publishers, Nig. Ltd.,192.

[3] Lands and Housing Rivers State (1992) Census News, Nigeria.

[4] Port Harcourt Master Plan (1975) Port Harcourt Master Plan, Stockholm.

[5] Greater Port Harcourt Spatial Development Plan (2009) Rivers State, Nigeria. www.ghpcity.com

[6] Balogun, O. (1979) PhD Dissertation Submitted to the Urban and Regional Planning Department, University of Ibadan, Ibadan.

[7] National Bureau of Statistics (NBS) (1991) Nigerian Population Statistics. 
Scientific Research Publishing (SCIRP) is one of the largest Open Access journal publishers. It is currently publishing more than 200 open access, online, peer-reviewed journals covering a wide range of academic disciplines. SCIRP serves the worldwide academic communities and contributes to the progress and application of science with its publication.

Other selected journals from SCIRP are listed as below. Submit your manuscript to us via either submit@scirp.org or Online Submission Portal.
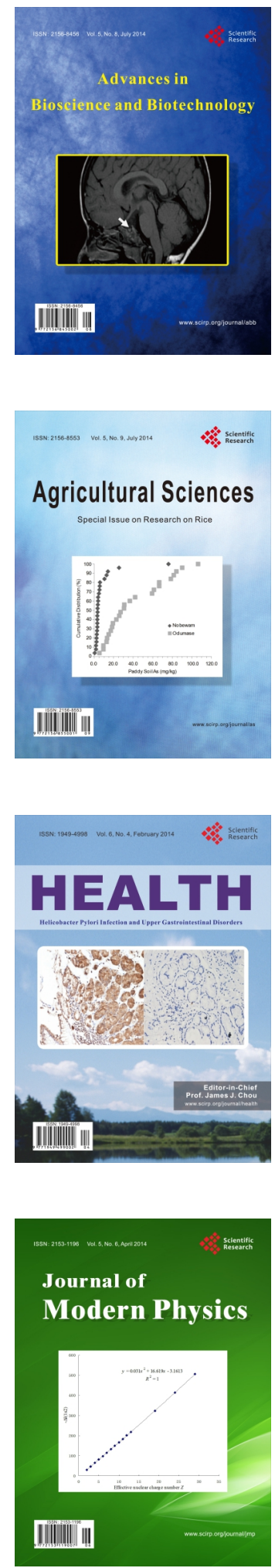
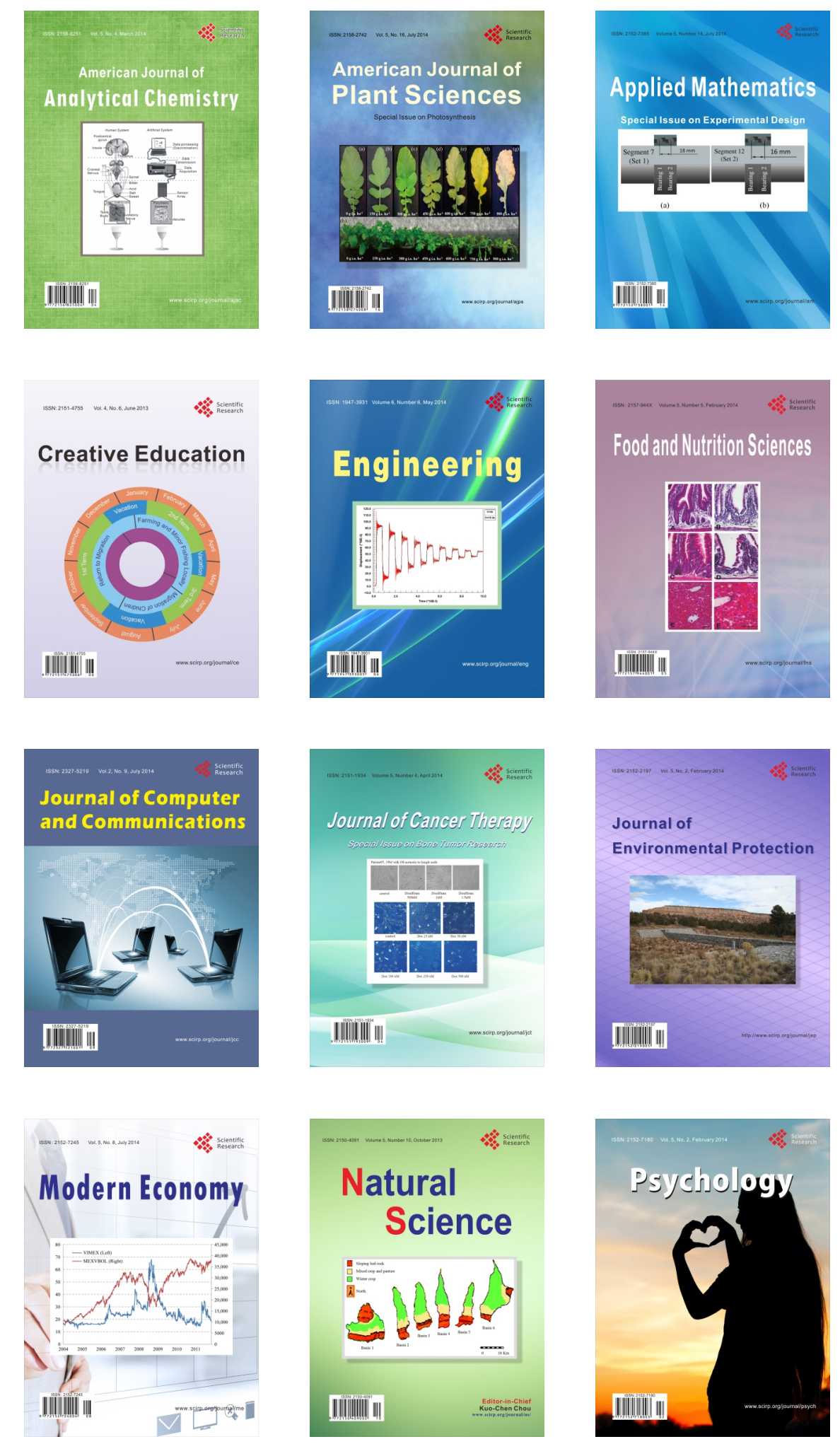